Jurnal Keperawatan Silampari

Volume 4, Nomor 1, Desember 2020

e-ISSN: 2581-1975

p-ISSN: 2597-7482

DOI: https://doi.org/10.31539/jks.v4i1.1618

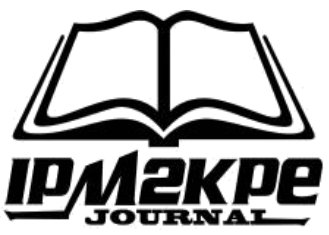

\title{
KESEJAHTERAAN SPIRITUAL DENGAN KEJADIAN INFEKSI OPORTUNISTIK PADA ODHA
}

\author{
Fitri Hastuti Ningsih ${ }^{1}$, Rohman Azaam ${ }^{2}$, Mustikasari ${ }^{3}$ \\ Univeritas Muhammadiyah Jakarta ${ }^{1,2}$ \\ Universitas Indonesia ${ }^{3}$ \\ fitridesfira@gmail.com ${ }^{1}$
}

\begin{abstract}
ABSTRAK
Tujuan penelitian ini untuk mengidentifikasi hubungan kesejahteraan spiritual dengan kejadian infeksi oportunistik pada ODHA. Metode penelitian deskriptif analitik dengan pendekatan cross sectional dan teknik random sampling. Hasil penelitian Analisis univariat menunjukan responden yang mengalami kejadian infeksi oportunistik $\leq 2$ sebanyak $199(89,2 \%)$ dan responden dengan kesejahteraan spiritual sedang sebanyak $127(57 \%)$. Hasil analisis bivariat menyatakan uji chi-square menjelaskan ada hubungan antara kesejahteraan spiritual dengan kejadian infeksi oportunistik (nilai $\mathrm{p}=0,007$ ), maka $\mathrm{OR}=3,689$ berarti kesejahteraan spiritual sedang mempunyai peluang 3,689 mengalami kejadian infeksi oportunistik $\leq 2$ dibandingkan dengan ODHA yang kesejahteraan spiritual ringan. Analisis multivariat menunjukan faktor pendidikan sebagai variabel dominan kejadian infeksi oportunistik $(\mathrm{OR}=6,378)$. Simpulan, ada hubungan kepatuhan tinggi terhadap kejadian infeksi oportunistik pada ODHA, Faktor dominan terhadap kejadian infeksi oportunistik adalah pendidikan.
\end{abstract}

Kata Kunci: HIV, Kejadian Infeksi Oportunistik, Kesejahteraan Spiritual

\begin{abstract}
This study aimed to identify the relationship between spiritual well-being and the incidence of opportunistic infections in PLHIV. Analytical descriptive research method with the cross-sectional approach and random sampling technique. The research univariate analysis results showed that respondents who experienced opportunistic infections $\leq 2$ were 199 (89.2\%), and respondents with moderate spiritual well-being were 127 (57\%). The results of the bivariate analysis state that the chi-square test explains that there is a relationship between spiritual well-being and the incidence of opportunistic infections ( $p$-value $=0.007$ ), so OR $=3.689$ means moderate spiritual well-being has a 3.689 chance of experiencing opportunistic infections $\leq$ two compared to PLWHA with mild spiritual well-being. Multivariate analysis showed that education was the dominant variable in the incidence of opportunistic infections $(O R=6.378)$. In conclusion, there is a high adherence to the incidence of opportunistic infections in PLWHA. The dominant factor in the incidence of opportunistic infections is education.
\end{abstract}

Keywords: HIV, Opportunistic Infection Incidence, Spiritual Well-being 


\section{PENDAHULUAN}

Human Immunodeficiency Virus atau Acquired immune deficiency syndrome (HIV/AIDS) merupakan masalah internasional karena jumlah penderita ekonomi, politik, kebudayaan dan demografi yang menjadi tantangan oleh negara maju maupun negara berkembang. HIV adalah penyakit kronis dan progresif yang memiliki masalah kesehatan kompleks (Hasanah et al., 2019). HIV adalah sebuah virus yang menyerang sistem kekebalan tubuh sebagai pertahanan alamiah untuk mencegah virus dan bakteri sebagai sumber penyakit (Siddik \& Uyun, 2018).

HIV merupakan penyakit menular karena infeksi virus dari kelompok selsel darah putih (sel T-Helper) dimana sel yang membuat zat anti dihancurkan dalam tubuh sehingga sel limfosit yang di infeksikannya akan merusak sel-sel tersebut, mengakibatkan menurunnya sistem kekebalan tubuh maka timbulnya penyakit infeksi ataupun penyakit oportunistik Infeksi oportunistik adalah infeksi yang menyerang tubuh saat kekebalan tubuh menurun ditimbulkan oleh patogen yang berasal dari luar tubuh seperti jamur,bakteri, protozoa atau virus bila tubuh dalam kondisi normal akan dikendali oleh pertahanan tubuh. Jenis patogen penyebab Infeksi Oportunistik bervariasi pada masing-masing wilayah.)

Perawat sebagai tenaga kesehatan yang profesional mempunyai intensitas dan interaksi paling banyak dalam memberikan pelayanan kesehatan terhadap pasien. Kualitas perawatan yang diberikan ditunjukkan dengan asuhan keperawatan comprehensive yang diberikan yang secara holistik mencakup aspek biologi, psikologi, sosial, dan spiritual. Analisis situasi saat pada institusi kesehatan di Indonesia menunjukkan hasil kontradiktif. Kenyataannya perawat belum secara kompeten dalam memberikan asuhan keperawatan dimana dalam proses penyembuhan pasien diperlukan dalam aspek spiritual (Saharuddin et al., 2018). Selain itu, masyarakat seringkali memberikan anggapan negatif bagi pasien ODHA, sehingga stigma negatif tersebut akan mempengaruhi ODHA dalam merespon terhadap adaptasi fisiologisnya termasuk juga masalah spiritualitasnya (Andri et al., 2020).

Saharuddin et al., (2018) mengatakan dalam implementasi kebutuhan spiritual belum dilakukan secara jelas karena ketidakpahaman perawat dalam aspek spiritual sehingga perawat dalam memberikan asuhan spiritual tidak kompeten karena selama masa pendidikannya tidak ada panduan dalam memberikan asuhan keperawatan spiritual.

Hasil penelitian Sastra et al., (2019) bahwa kesejahteraan spiritual memiliki hubungan yang kuat dengan kesehatan mental yang dapat membuat pasien lebih optimis terhadap penyakitnya. Perkembangan kesejahteraan spiritual individu berhubungan dengan perkembangan dimensi spiritual, penghayatan keagamaan dan perkembangan. Kesejahteraan spiritual sebagai konsep mandiri dalam konteks layanan bimbingan dan konseling yang berkembang dalam diri individu.

Pasien dewasa dengan HIV, spiritualitas berhubungan dengan kesehatan fisik dan mental serta memproteksi dari terjadinya depresi. Pada orang dengan kepercayaan spiritual negatif, perjuangan spiritual dapat meningkatkan distress, progresivitas penyakit dan bahkan kematian juga gagal pemberian terapi ARV, tidak kontrol obat dan nutrisi menurun maka terjadinya peningkatan infeksi oportunistik Sedangkan pada orang yang memiliki kepercayaan spiritual positif, spiritualitas dapat mempengaruhi kesejahteraan spiritualnya terutama pada akhir kehidupan untuk hidup sehat dengan patuh minum obat ARV, kontrol obat dan menjaga nutrisi maka terjadinya penurunan infeksi oportunistik, sehingga kesejahteraan spiritual merupakan 
aspek penting yang perlu diperhatikan seperti hal kesejahteraan fisik, psikologis, dan sosial.

Kebutuhan spiritualitas pasien menjadi bagian integral dalam kesehatan fisik, mental dan emosional. Kesejahteraan secara spiritual merupakan kondisi seseorang yang menunjukkan aspek positif dari spiritualitasnya. Penelitian yang dilakukan Handayani \& Fourianalistyawati (2018) menjelaskan bahwa kesejahteraan spiritual adalah suatu keadaan yang merefleksikan perasaan positif, perilaku dan kognisi dari hubungan dengan diri sendiri dan orang lain, serta hubungan dengan yang maha kuasa (transcendent) dan alam, yang pada akhirnya memberikan individu suatu rasa identitas, sikap positif, keutuhan, rasa damai, kepuasan, keindahan, suka cita, rasa puas, keharmonian batin, serta tujuan dan arah dalam hidup.

Penelitian sebelumnya hanya melakukan penelitian tentang adaptasi fisiologis pada ODHA dan kesejahteraan spiritual secara umum. Namun penelitian ini berfokus pada kesejahteraan spiritual dengan kejadian infeksi oportunistik pada ODHA.

\section{METODE PENELITIAN}

Penelitian ini non eksperimen deskriptif analitik dengan menggunakan metode deskriptif cross sectional yang mempelajari dan menganalisis Hubungan kesejahteraan spiritual dengan kejadian infeksi oportunistik pada ODHA di Poliklinik Matahari Di Rumah Sakit Bhayangkara Tk I R.Said Sukanto Jakarta Timur. Penelitian ini bertujuan menggambarkan suatu peristiwa yang dilakukan secara sistematik juga mencari hubungan variabel independen dan dependen.

\section{HASIL PENELITIAN}

Analisis Univariat

Tabel. 1

Distribusi Responden Berdasarkan

Kejadian Infeksi

\begin{tabular}{ccc}
\hline Kejadian infeksi oportunistik & $\mathrm{n}$ & $\%$ \\
\hline$>2$ infeksi oportunistik & 24 & 10.8 \\
$\leq 2$ infeksi oportunistik & 199 & 89.2 \\
\hline Total & 223 & 100.0 \\
\hline
\end{tabular}

Berdasarkan tabel 1 menunjukkan bahwa sebagian besar responden mengalami $\leq 2$ infeksi oportunistik yaitu sebanyak 199 orang $(89,2 \%)$.

Tabel. 2

Distribusi Responden Berdasarkan

Kesejahteraan Spiritual

\begin{tabular}{ccc}
\hline Kesejahteraan Spiritual & $\mathrm{n}$ & $\%$ \\
\hline Rendah & 96 & 43.0 \\
Sedang & 127 & 57.0 \\
\hline Total & 223 & 100.0 \\
\hline
\end{tabular}

Berdasarkan tabel 2 menunjukkan bahwa kesejahteraan spiritual diketahui bahwa sebagian besar responden sedang yaitu sebanyak 127 orang (57\%). 


\section{Analisa Bivariat}

Tabel. 3

Hubungan antara Kesejahteraan Spiritual dengan Kejadian Infeksi Oportunistik

\begin{tabular}{|c|c|c|c|c|c|c|c|c|}
\hline \multirow{3}{*}{$\begin{array}{c}\text { Kesejahteraa } \\
\text { n Spritual }\end{array}$} & \multicolumn{4}{|c|}{$\begin{array}{c}\text { Kejadian infeksi } \\
\text { oportunistik }\end{array}$} & \multicolumn{2}{|c|}{ Total } & \multirow{3}{*}{$p$ value } & \multirow{3}{*}{$\begin{array}{c}\text { OR } \\
(95 \% C I)\end{array}$} \\
\hline & \multicolumn{2}{|c|}{$\begin{array}{c}>2 \text { infeksi } \\
\text { oportunistik }\end{array}$} & \multicolumn{2}{|c|}{$\begin{array}{c}\leq 2 \text { infeksi } \\
\text { oportunistik }\end{array}$} & \multirow[t]{2}{*}{$\mathrm{n}$} & \multirow[t]{2}{*}{$\%$} & & \\
\hline & $\mathrm{N}$ & $\%$ & $\mathrm{n}$ & $\%$ & & & & \\
\hline Rendah & 17 & 17,7 & 79 & 82,3 & 96 & 100 & \multirow{3}{*}{0.007} & \multirow{3}{*}{$\begin{array}{c}3,689 \\
(1,463-9,302)\end{array}$} \\
\hline Sedang & 7 & 5,5 & 120 & 94,5 & 127 & 100 & & \\
\hline Total & 24 & 10.8 & 199 & 89.2 & 223 & 100 & & \\
\hline
\end{tabular}

Berdasarkan tabel 3 hasil analisis hubungan kesejahteraan spiritual sedang sebanyak $120(94,5 \%)$ mengalami kejadian infeksi oportunistik $\leq 2$, ada hubungan yang signifikan kesejahteraan spiritual dengan kejadian infeksi oportunistik dengan nilai $\mathrm{p}=0.007, \mathrm{R}=3,689$ artinya ODHA dengan kesejahteraan spiritual sedang mempunyai peluang 3,689 kali terhindar dari infeksi oportunistik $\leq 2$ dibandingkan dengan ODHA yang kesejahteraan spiritualnya rendah. Hasil analisis hubungan usia dengan kejadian infeksi oportunistik $\leq 2$ sebanyak $178(89,0 \%)$ pada ODHA. Uji statistik diperoleh nilai $\mathrm{p}=1,000$, tidak ada hubungan yang signifikan antara usia dengan kejadian infeksi oportunistik karena $\mathrm{p}$ value $=0,05$.

Tabel. 4

Hubungan antara Distribusi Demograff dengan Kejadian Infeksi

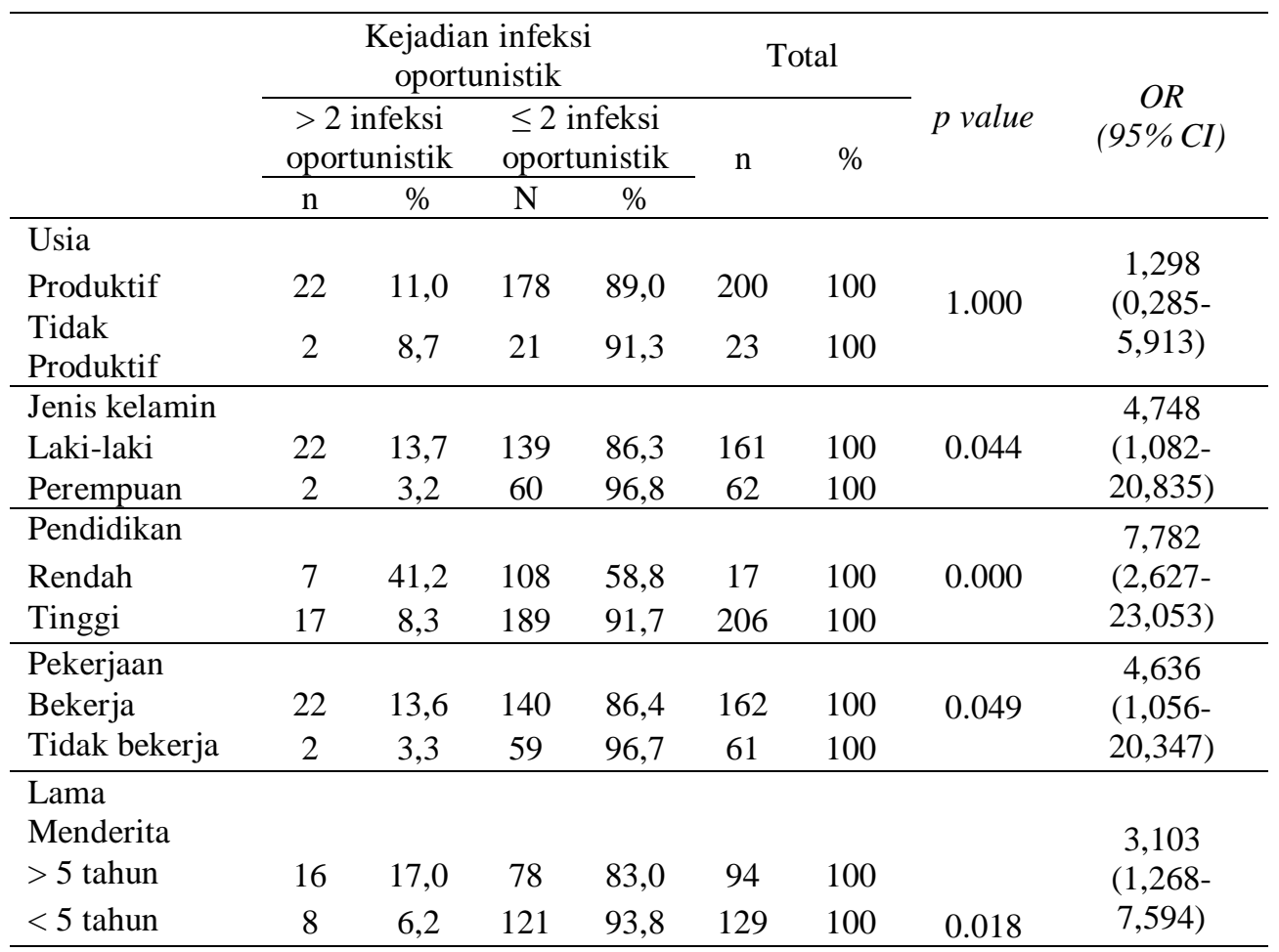




\begin{tabular}{lcccccccc}
\hline $\begin{array}{l}\text { Status } \\
\text { Pernikahan }\end{array}$ & & & & & & & & 3,013 \\
$\begin{array}{l}\text { Belum } \\
\text { Menikah }\end{array}$ & 19 & 14,6 & 111 & 85,4 & 130 & 100 & 0.048 & $\begin{array}{c}(1,082- \\
\text { Menikah }\end{array}$ \\
\hline CD4 & 5,4 & 88 & 94,6 & 93 & 100 & & \\
Berisiko & 23 & 13,9 & 143 & 86,1 & 166 & 100 & 0.022 & $(1,188-$ \\
Tidak berisiko & 1 & 1,8 & 56 & 98,2 & 57 & 100 & & $68,294)$ \\
\hline Kepatuhan & & & & & & & & \\
Pengobatan & & & & & & & & 1,788 \\
Rendah & 10 & 21,3 & 37 & 78,7 & 47 & 100 & 0.020 & $(1,094-$ \\
Sedang & 4 & 8,7 & 42 & 91,3 & 46 & 100 & & $2,922)$ \\
Tinggi & 10 & 7,7 & 120 & 82,3 & 130 & 100 & & \\
\hline \multicolumn{1}{c}{ Total } & 24 & 10.8 & 199 & 89.2 & 223 & 100 & & \\
\hline & & & & & & & & \\
\hline
\end{tabular}

Berdasarkan tabel 4 hasil analisis hubungan antara usia dengan kejadian infeksi oportunistik diperoleh bahwa ada sebanyak 178 (89,0\%) ODHA dengan usia produktif mengalami kejadian infeksi oportunistik $\leq 2$ sedangkan usia tidak produktif ada $21(91,3 \%)$ mengalami kejadian infeksi oportunistik $\leq 2$. Hasil uji statistik diperoleh nilai $\mathrm{p}=1,000$ maka dapat disimpulkan tidak ada hubungan yang signifikan antara usia dengan kejadian infeksi oportunistik karena $\mathrm{p}$ value $=0,05$.

Tabel. 5

Hasil Analisis Variabel Independent dengan Kejadian Infeksi Oportunistik

\begin{tabular}{clcc}
\hline NO & \multicolumn{1}{c}{ Variabel } & P Value & Hasil \\
\hline 1 & Kesejahteraan Spritual & 0,007 & Kandidat multivariate \\
2 & Usia & 1,000 & Bukan Kandidat multivariat \\
3 & Jenis Kelamin & 0,044 & Kandidat multivariat \\
4 & Pendidikan & 0,000 & Kandidat multivariat \\
5 & Pekerjaan & 0,049 & Kandidat multivariat \\
6 & Lama menderita & 0,018 & Kandidat multivariat \\
7 & Status pernikahan & 0,048 & Kandidat multivariat \\
8 & CD4 & 0,022 & Kandidat multivariat \\
9 & Kepatuhan & 0,020 & Kandidat multivariat \\
\hline
\end{tabular}

Berdasarkan tabel 5 hasil analisis antara variabel independen dengan variabel dependen terlihat bahwa variabel independent yang memiliki nilai $\mathrm{P}<0,25$ adalah kesejahteraan spritual, pendidikan, jenis kelamin, pekerjaan, lama menderita, status pernikahan, CD4 dan kepatuhan ARV yang dimasukkan dalam uji multivariate, sedangkan usia tidak menjadi kandidat karena nilai pvalue $>0,25$.

Tabel. 6

Hasil Analisis Multivariate Regresi Logistic $(\mathrm{n}=223)$

\begin{tabular}{clccc}
\hline Tahap & \multicolumn{1}{c}{ Variabel } & Sig & OR & Perubahan OR \\
\hline \multirow{4}{*}{ I } & Kesejahteraan Spritual & 0.028 & 3.295 & \\
& Jenis Kelamin & 0.453 & 2.040 & \\
& Pendidikan & 0.007 & 6.387 & \\
& Pekerjaan & 0.124 & 4.392 & \\
& Lama menderita & 0.005 & 4.801 & \\
\hline
\end{tabular}




\begin{tabular}{|c|c|c|c|c|}
\hline & Status pernikahan & 0.025 & 3.953 & \\
\hline & CD4 & 0.085 & 6.329 & \\
\hline & Kepatuhan & 0.053 & 1.781 & \\
\hline \multirow{7}{*}{ II } & $\begin{array}{l}\text { Kesejahteraan Spritual } \\
\text { Jenis Kelamin }\end{array}$ & 0.029 & 3.265 & 0.93 \\
\hline & Pendidikan & 0.007 & 6.206 & 2.83 \\
\hline & Pekerjaan & 0.041 & 6.121 & 39.37 \\
\hline & Lama menderita & 0.005 & 4.794 & 0.15 \\
\hline & Status pernikahan & 0.019 & 4.201 & 6.28 \\
\hline & CD4 & 0.082 & 6.425 & 1.52 \\
\hline & Kepatuhan & 0.044 & 1.821 & 2.24 \\
\hline \multirow{8}{*}{ III } & Kesejahteraan Spritual & 0.026 & 3.316 & 0.64 \\
\hline & Jenis Kelamin & 0.097 & 4.295 & 110.50 \\
\hline & Pendidikan & 0.008 & 6.146 & 3.78 \\
\hline & Pekerjaan & & & \\
\hline & Lama menderita & 0.005 & 4.635 & 3.45 \\
\hline & Status pernikahan & 0.027 & 3.754 & 5.02 \\
\hline & CD4 & 0.095 & 5.937 & \\
\hline & Kepatuhan & 0.069 & 1.712 & 3.91 \\
\hline \multirow{7}{*}{ IV } & Kesejahteraan Spritual & 0.011 & 3.867 & 17.36 \\
\hline & Jenis Kelamin & 0.408 & 2.161 & 5.92 \\
\hline & Pendidikan & 0.004 & 6.914 & 8.25 \\
\hline & Pekerjaan & 0.143 & 4.078 & 7.13 \\
\hline & Lama menderita & 0.006 & 4.513 & 6.00 \\
\hline & $\begin{array}{l}\text { Status pernikahan } \\
\text { CD4 }\end{array}$ & 0.019 & 4.074 & 3.06 \\
\hline & Kepatuhan & 0.034 & 1.881 & 5.61 \\
\hline
\end{tabular}

Berdasarkan tabel 6 hasil analisis pada tahap I di atas terlihat dari kedelapan variabel ada yang mempunyai nilai $\mathrm{P}>0,05$ artinya yaitu jenis kelamin dimana variabel tersebut dikeluarkan dari pemodelan, sedangkan variable yang dipertahankan sebagai dalam pemodelan adalah kesejahteraan spritual, pendidikan, pekerjaan, lama menderita, status pernikahan, CD4 dan kepatuhan ARV. Pada langkah tahap II setelah variable jenis kelamin dikeluarkan dihitung perubahan nilai OR terhadap variabel sikap dan lingkungan keluarga, dimana terjadi perubahan nilai OR diatas 10\% dan variable jensi kelamin dimasukkan kembali dan mengeluarkan variabel pekerjaan.

Tabel. 7

Hasil Analisa Uji Interaksi Variabel Kesejahteraan Spiritual, Kepatuhan, Pendidikan, Jenis Kelamin, CD 4 dalam Hubungan dengan Kejadian Infeksi Oportunistik

\begin{tabular}{clc}
\hline No & Variabel & P Value \\
\hline 1 & Pendidikan*Kesejahteraan Spritual & 0,176 \\
2 & Kepatuhan*Kesejahteraan spiritual & 0,51 \\
3 & Pendidikan*Kepatuhan & 0,375 \\
4 & Jenis Kelamin*Kesejahteraan Spritual & 0,74 \\
5 & CD4*Kepatuhan & 0,226 \\
\hline
\end{tabular}

Berdasarkan tabel 7 menunjukkan tidak terdapat interaksi yang bermakna dari masing-masing variabel dalam hubungannya dengan kejadian infeksi oportunistik ( $\mathrm{p}$ $\geq 0,05)$. 
Tabel. 8

Hasil Pemodelan Akhir Multivariate

Regresi Logistic

\begin{tabular}{lrrrrrr}
\hline \multicolumn{1}{c}{ Variabel } & \multirow{2}{*}{ B } & \multirow{2}{*}{ Wald } & \multirow{2}{*}{ Sig } & \multirow{2}{*}{ OR } & \multicolumn{2}{c}{ 95\% CI } \\
\cline { 6 - 8 } & & & & & Lower & Upper \\
\hline Kesejahteraan Spritual & 1.192 & 4.799 & 0.028 & 3.295 & 1.134 & 9.577 \\
Jenis Kelamin & 0.713 & 0.563 & 0.453 & 2.040 & 0.317 & 13.149 \\
Pendidikan & 1.854 & 7.353 & 0.007 & 6.387 & 1.672 & 24.397 \\
Pekerjaan & 1.480 & 2.364 & 0.124 & 4.392 & 0.666 & 28.958 \\
Lama menderita & 1.569 & 7.949 & 0.005 & 4.801 & 1.613 & 14.288 \\
Status pernikahan & 1.374 & 4.998 & 0.025 & 3.953 & 1.185 & 13.189 \\
CD4 & 1.845 & 2.963 & 0.085 & 6.329 & 0.774 & 51.742 \\
Kepatuhan & 0.577 & 3.748 & 0.053 & 1.781 & 0.993 & 3.196 \\
& -13.082 & 20.904 & 0.000 & 0.000 & & \\
\hline
\end{tabular}

Berdasarkan tabel 8 menunjukkan bahwa variabel yang bisa dipertahankan kesejahteraan spritual, jenis kelamin, pendidikan, pekerjaan, lama menderita, status pernikahan, CD4 dan kepatuhan ARV. Dari kedelapan variabel terlihat bahwa variabel yang dominan berhubungan terhadap kejadian infeksi oportunistik adalah pendidikan, dengan $\mathrm{p}$ value $<0,05$ didapat nilai $\mathrm{OR}=6.387$, setelah dikontrol oleh variabel kesejahteraan spritual, jenis kelamin, pekerjaan, lama menderita, status pernikahan, CD4 dan kepatuhan ARV.

\section{PEMBAHASAN}

Berdasarkan penelitian yang telah dilakukan didapatkan bahwa ada hubungan yang signifikan antara kesejahteraan spiritual dengan kejadian infeksi oportunistik $\leq$ 2. Domain Personal mengatakan pada pasien HIV dengan infeksi oportunistik sejalan penelitian ini bahwa bila Kesejahteraan berkontribusi yang negatif dengan berbagai masalah kesehatan mental dirinya dan kesejahteraan yang baik berkontribusi pada penurunan masalah kesehatan dirinya. Kesejahteraan secara signifikan berkorelasi negatif dengan depresi dan kecemasan. Dengan demikian, kesejahteraan sangat berpengaruh pada kehidupan personal dapat mengurangi resiko masalah kesehatan pada masa sekarang dan akan datang (Wahyuni et al., 2018).

Batlajery \& Soegijono (2019) mengatakan bahwa salah satu pengaruh terjadinya penyakit adanya unsur kondisi emosional seseorang yang berlebihan dililhat dari perkembangan penyakitnya juga emosi negatif yang kuat berpengaruh terhadap sistem imun tubuhnya. Individu dikatakan sejahtera apabila individu menerima kehidupannya, mempunyai hubungan positif dengan orang lain, berani menghadapi masalah, berani mengembangkan potensi yang dimiliki secara terus menerus, mampu menentukan tujuan hidupnya dan mengetahui makna hidupnya pada waktu sekarang dan dahulu serta sanggup membuat lingkungan yang cocok dengan keadaan tubuh individu.

Hasil variabel kesejahteraan spiritual diketahui bahwa sebagian besar responden sedang yaitu sebanyak 127 orang (57\%) dari responden 223 orang berarti pasien ODHA masih membutuhkan kebutuhan spiritualitas terhadap dirinya untuk mencapai kesejahteraan tinggi, pasien ODHA mempunyai keinginan untuk sembuh, berusaha untuk berobat ke Poliklinik Matahari secara rutin dan minum obat ARV sesuai 
aturannya sehingga tidak putus obat, menjaga pola perilaku hidup sehat dengan setia terhadap pasangannya sehingga bisa melanjutkan kehidupannya agar dirinya menjadi lebih mempunyai tujuan hidup untuk sembuh.

Hasil penelitian ini sejalan dengan penelitian Sastra et al., (2019) bahwa kesejahteraan spiritual memiliki hubungan yang kuat dengan kesehatan mental yang dapat membuat pasien lebih optimis terhadap penyakitnya. Perkembangan kesejahteraan spiritual individu berhubungan dengan perkembangan dimensi spiritual, penghayatan keagamaan dan perkembangan. Kesejahteraan spiritual sebagai konsep mandiri dalam konteks layanan bimbingan dan konseling yang berkembang dalam diri individu. Menurut Imaduddin (2017) mengatakan bahwa kesejahteraan spiritual sebagai konsep mandiri dalam konteks layanan bimbingan dan konseling yang berkembang dalam individu sesuai dengan konsep.

Berdasarkan penelitian yang telah dilakukan didapatkan menunjukkan bahwa tidak ada hubungan yang signifikan antara usia dengan kejadian infeksi oportunistik $\leq 2$. Hasil penelitian ini sejalan dengan penelitian Kasana et al., (2019) menyatakan bahwa usia tidak terdapat hubungan yang bermakna secara statistik antara usia penderita HIV dengan survival penderita HIV. Hasil penelitian ini sejalan dengan penelitian Manalu et al., (2019) menyatakan tidak ada pengaruh umur dengan kejadian infeksi HIV bahwa dilapangan semua umur bisa terinfeksi HIV karena penularan HIV yang berbeda-beda walaupun penularannyai ominasi oleh heteroseks.

Hubungan antara jenis kelamin dengan kejadian infeksi oportunistik Berdasarkan penelitian yang telah dilakukan didapatkan bahwa nilai $\mathrm{p}=0,044$ dapat disimpulkan ada hubungan yang signifikan antara jenis kelamin dengan kejadian infeksi oportunistik $\leq 2$. Hasil penelitian ini sejalan dengan penelitian Manalu et al., (2019) mengatakan bahwa ada pengaruh jenis kelamin dengan kejadian infeksi HIV, dimana proporsi kasus AIDS pada laki-laki mencapai $78 \%$ dan perempuan sekitar $21 \%$ hal ini menunjukkan bahwa pengguna jarum suntik mayoritas adalah laki-laki juga pelangggan seks komersial secara umum kebanyakan laki-laki.

Hubungan antara Pendidikan dengan Kejadian infeksi oportunistik Berdasarkan penelitian yang telah dilakukan didapatkan bahwa nilai $\mathrm{p}=0,000$ maka dapat disimpulkan ada hubungan yang signifikan antara pendidikan dengan kejadian infeksi oportunistik $\leq 2$ Dalam model multivariat bahwa variabel yang dominan berhubungan terhadap kejadian infeksi oportunistik adalah pendidikan, dengan $\mathrm{p}$ value $<0,05$ didapat nilai $\mathrm{OR}=6.387$, maka dengan pendidikan tinggi akan mempengaruhi kejadian oportunistik sebesar 6 kali lebih tinggi dibandingkan dengan pendidikkan rendah.

Hasil penelitian ini sejalan dengan penelitian Anggraeni \& Aisah (2018) mengatakan bahwa proses belajar akan mempengaruhi seseorang maka semakin tinggi pendidikannya akan meningkatkan pengetahuannya dalam mendapatkan berbagai informasi. Dari gambaran statitstik beberapa hasil penelitian diatas dapat disimpulkan bahwa tingkat pendidikan seseorang mempunyai kemampuan menerima informasi dan mengubah perilaku ke arah yang lebih baik sehingga seseorang memiliki pendidikan tinggi mempunyai wawasan yang luas sehingga menjadi teladan dalam kehidupan sehari-hari.

Berdasarkan penelitian yang telah dilakukan didapatkan bahwa ada hubungan yang signifikan antara pekerjaan dengan kejadian infeksi oportunistik $\leq 2$. Penelitian yang dilakukan Saktina \& Satriyasa (2017) mengatakan bahwa orang yang bekerja dan mempunyai penghasilan sendiri akan menjadi faktor pendorong untuk melakukan 
sesuatu yang diinginkan sesuai dengan penghasilannya termasuk membeli seks yang merupakan perilaku seks berisiko terhadap rentannya infeksi. Namun, faktor stres terhadap pekerjaan, jauh dari keluarga (istri dan keluarga), kurangnya pengetahuan tentang HIV dan rendahnya kesadaran tentang tindakan pencegahan penularan HIV diidentifikasi sebagai penyebab penularan HIV.

Berdasarkan penelitian yang telah dilakukan didapatkan bahwa ada hubungan yang signifikan antara lama menderita dengan kejadian infeksi oportunistik $\leq 2$. Ada hubungan yang signifikan antara antara status pernikahan belum menikah dengan kejadian infeksi oportunistik $\leq 2$.

Hasil penelitian ini sejalan dengan penelitian Sugiarto (2017) mengatakan bahwa peranan seksual dimiliki antara seorang laki-laki yang sudah menikah dan yang belum menikah dalam status perkawinan. Laki-laki yang sudah menikah akan memiliki perilaku yang sehat dan bertanggung jawab dalam melakukan hubungan seksual dengan pasangannya tidak menginginkan dampak negatif dalam melakukan hubungan seksual akan tetapi seseorang yang berstatus belum menikah mempunyai tingkat perilaku seks yang lebih berisiko karena untuk melampiaskan hasrat seksualnya mereka cenderung.

Berdasarkan penelitian yang telah dilakukan didapatkan bahwa ada hubungan yang signifikan antara CD4 berisiko dengan kejadian infeksi oportunistik $\leq 2$. Hasil penelitian ini sejalan dengan penelitian Ladyani \& Kiristianingsih (2019) bahwa infeksi HIV menyebabkan penurunan sistem imun progresif akibat jumlah dan fungsi sel CD4 yang berkurang, CD4 menjadi dua kelompok yaitu CD4 < 350 dan CD4 > 350 menyatakan bahwa pasien dengan jumlah CD4 $<350 \mathrm{sel} / \mathrm{mm} 3$ memiliki kerentanan empat kali dalam perkembangan infeksi oportunistik dibanding dengan jumlah CD4 > $350 \mathrm{sel} / \mathrm{mm} 3$ sehingga bila jumlah CD4 yang rendah menyebabkan individu lebih rentan terkena infeksi oportunistik. Berdasarkan penelitian yang telah dilakukan didapatkan bahwa ada hubungan yang signifikan antara kepatuhan minum ARV dengan kejadian infeksi oportunistik.

\section{SIMPULAN}

Tidak ada hubungan usia dengan kesejahteraan spiritual terhadap kejadian infeksi oportunistik pada ODHA. Ada hubungan pendidikan, jenis kelamin, pekerjaan, status pernikahan, lama menderita CD4 Berisiko dan kepatuhan terhadap kejadian infeksi oportunistik pada ODHA. Fsktor dominan terhadap kejadian infeksi oportunistik adalah pendidikan.

\section{SARAN}

Bagi institusi Yayasan Perkembangan spiritual semata dipandang sebagai bagian alamiah dalam perkembangan individu. Tahapan utama yang harus ada dalam proses konseling yang ditawarkan adalah proses asesmen dan intervensi sehingga dibutuhkan konsep yang terpisah dari religiusitas, sehingga perkembangan spiritual semata dipandang sebagai bagian alamiah dalam perkembangan individu. Tahapan utama yang harus ada dalam proses konseling yang ditawarkan adalah proses asesmen dan intervensi.

Bagi insititusi pendidikan dapat dijadikan data dan informasi dalam meningkatkan kesejahteraan spiritual terhadap kejadian infeksi oportunistik dan sebagai tambahan refrensi Keperawatan Medikal. 
Bagi peneliti selanjutnya diharapkan hasil penelitian ini dapat dijadikan sebagai dasar untuk penelitian lebih lanjut dilakukan kompetensi perawat spiritual melakukan intervensi kebutuhan spiritual dalam kesejahteraan spiritual dengan kejadian infeksi oportunistik pada ODHA.

\section{DAFTAR PUSTAKA}

Andri, J., Ramon, A., Padila, P., Sartika, A., \& Putriana, E. (2020). Pengalaman Pasien ODHA dalam Adaptasi Fisiologis. Journal of Telenursing (JOTING), 2(2), 127141. https://doi.org/10.31539/joting.v2i2.1397

Anggraeni, M. Y. R., \& Aisah, S. (2018). Perilaku Pencegahan HIV/AIDS Masyarakat Desa Waru. Prosiding Seminar Nasional Mahasiswa Unimus, 1(2016), 302-309

Batlajery, T. M., \& Soegijono, S. P. (2019). Persepsi Kesehatan dan Well-Being Penderita Hipertensi di Desa Ritabel. Insight: Jurnal Pemikiran Dan Penelitian Psikologi, 15(1), 39. https://doi.org/10.32528/ins.v15i1.1630

Handayani, F. P., \& Fourianalistyawati, E. (2018). Depresi dan Kesejahteraan Spiritual pada Ibu Hamil Risiko Tinggi. Jurnal Psikologi Teori Dan Terapan, 8(2), 145. https://doi.org/10.26740/jptt.v8n2.p145-153

Hasanah, U., Ibrahim, K., \& Sriati, A. (2019). Effects of Spiritual Counseling on Spiritual Health-Quality of Life in Patients with HIV/AIDS. Nurse Media Journal of Nursing, 9(1), 13. https://doi.org/10.14710/nmjn.v9i1.22983

Imaduddin, A. (2017). Spiritualitas Dalam Konteks Konseling. Journal of Innovative Counseling: Theory, Practice \& Research, 1(1), 1-8. http://journal.umtas.ac.id/index.php/innovative_counseling

Kasana, R. U., Ike, H., \& Siskaningrum, A. (2019). Hubungan antara Self Awareness dengan Kadar Glukosa Darah pada Pasien Dm Tipe 2 (Studi Di Poli Penyakut dalam RSUD Jombang). Hospital Majapahit, 11(1), 11-16. https://doi.org/https://doi.org/10.5281/zenodo.3514646

Ladyani, F., \& Kiristianingsih, A. (2019). Hubungan antara Jumlah CD4 pada Pasien yang Terinfeksi HIV / AIDS dengan Infeksi Oportunistik di Rumah Sakit Umum Abdul Moeloek Bandar Lampung Tahun 2016. 3(1), 34-41

Manalu, R. M., Harahap, S. Y., \& Sinurat, I. (2019). Faktor-Faktor yang Mempengaruhi Kejadian Infeksi HIV pada Usia Produktif di Komite Aids Hkbp Balige. Indonesian Trust Health Journal, 2(2), 190-198. https://doi.org/10.37104/ithj.v2i2.35

Saharuddin, S., Amir, S., \& Rosmina, R. (2018). Penerapan Model Pelayanan Keperawatan Berbasis Spiritual Ditinjau dari Aspek Proses Asuhan Keperawatan Spritual di Rumah Sakit Islam Faisal Makassar. Hospital Majapahit, 10(1), 8-22. https://doi.org/10.5281/zenodo.3514585

Saktina, P., \& Satriyasa, B. (2017). Karakteristik Penderita Aids Dan Infeksi Oportunistik Di Rumah Sakit Umum Pusat Sanglah Denpasar Periode Juli 2013 Sampai Juni 2014. E-Jurnal Medika Udayana, 6(3), 1-6. https://ojs.unud.ac.id/index.php/eum/article/view/29100

Sastra, L., Wahyudi, W., \& Faradilla, I. (2019). Hubungan Kesehatan Spiritual dengan Kualitas Hidup Orang dengan Hiv/Aids di Yayasan Lantera Minangkabau Support Padang. Jurnal Kesehatan Mercusuar, 2(2), 7-12. https://doi.org/https://doi.org/10.36984/jkm.v2i2.62 
Siddik, I. N., \& Uyun, Q. (2018). Khusnudzon dan Psychological Well Being pada Orang dengan HIV/AIDS. Psikis: Jurnal Psikologi Islami, 3(2), 86-93. 10.19109/psikis.v3i2.1735

Sugiarto, S. (2017). Hubungan Status Pernikahan dan Kepemilikan Kondom dengan Penggunaan Kondom Saat Melakukan Hubungan Seksual pada Pasangan Tidak Tetap Pengguna Napza Suntik. Jurnal Kesehatan Terpadu, 1(2), 44-48. http://dx.doi.org/10.32883/hcj.v3i1.97

Wahyuni, E., Nurihsan, J., \& Yusuf, S. (2018). Kesejahteraan Mahasiswa: Implikasi Terhadap Program Konseling di Perguruan Tinggi. Insight: Jurnal Bimbingan Konseling, 7(1), 96-106. https://doi.org/10.21009/insight.071.08 